\title{
The Constitutional and Legal Basis of Price Regulation in Ethiopia
}

Fekadu Petros Gebremeskel*

\begin{abstract}
This article examines price regulation with its various objectives, forms and contexts. Navigating through the economic literature (that shows price regulation as a futile exercise for controlling inflation and solving commodity scarcity), the article analyses the constitutional foundations and the legislative enactments that authorize price regulation in Ethiopia. While there is a strong legal authority under the Constitution to regulate prices, there is lack of detailed standards to distinguish between the proper and improper exercise of price regulation power. Distinction is made between price regulation in normal times vis-à-vis price regulation during emergencies, and I argue that price regulation during emergencies should be evaluated against separate standards. With regard to price regulation in normal times, the recently enacted administrative procedure proclamation may help in solving the lack of standards.
\end{abstract}

Key terms

Price regulation · Price control $\cdot$ FDRE Constitution $\cdot$ Basic commodities

DOI http://dx.doi.org/10.4314/mlr.v14i1.5

This article is licensed under a Creative Commons Attribution-

NonCommercial-NoDerivs (CC BY-NC-ND)

Received: 6 May 2020 (Version 2)

Accepted: 4 September 2020

Suggested citation:

Fekadu Petros Gebremeskel (2020), 'The Constitutional and Legal Basis of Price

Regulation in Ethiopia', 14 Mizan Law Review 1: 31-60

- Fekadu Petros Gebremeskel (Asst. Prof.), Addis Ababa University, School of Law; and Consultant and Attorney at Law.

Email: pehfekadu@gmail.com; fekadu.petros@aau.edu.et.

ORCID: https://orcid.org/0000-0001-9150-3866

I thank the two anonymous reviewers for their careful reading and insightful comments which helped in improving this article. The article was initially submitted for Economic Regulation Class in the PhD Program at Addis Ababa University School of Law. I thus thank Prof. Tilahun Teshome for his comments on the initial draft. 


\section{Introduction}

Regulation has been generally taken as the main activity of government. While regulation affects both individuals and business entities, economic regulation is primarily addressed to businesses and entrepreneurs. Even though regulation is currently accepted as the proper function of government, the alternatives between higher and lower degrees of regulation have become one of the main topics of political discourse. This has given rise to the politicization of regulatory choices and interventions, and the sidelining or neglect of sound economic and legal considerations. As Cramton argued, "the net effect of the busy humming of the regulatory machinery may be only to irritate entrepreneurs and to enrich their lawyers, without effecting a fundamental alteration in the state of affairs that would have existed in the absence of regulation."1

This neglect of economic considerations is more prevalent in price regulation than in the broader field of economic regulation. In respect to price regulation, various objectives are intended to be achieved when governments interfere in the determination of prices. These objectives include averting inflation of commodity prices, fighting anti-competitive behavior, promoting social policy and public health, and other purposes. However, a plethora of documented evidence shows that price regulation seldom achieves economic goals such as controlling inflation or solving supply problems, though it may help solve some social problems. This has led many commentators to conclude that price regulation is more of a political decision than economic. Yet, the political decision to use governmental power to regulate prices emanates from the law.

The aim of this article is not to uncover the effects of the various price control interventions in Ethiopia. Its aim is to explain the nature of price regulation, the constitutional and legal basis of price regulation and to briefly show some of the price regulation exercises in recent times in Ethiopia. The article further attempts to explore the economic literature on price regulation and the various ad-hoc and permanent measures taken by governmental authorities in Ethiopia in regulating prices. An evaluation of the legal basis of price regulation raises two main questions. The first question relates to interference in the contractual choices of parties to contract, and the second concern interrogates the economic wisdom of price setting from macroeconomic point of view.

\footnotetext{
${ }^{1}$ Roger C. Cramton (1964), The Effectiveness Of Economic Regulation: A Legal View (Cornell Law Faculty Publications) p. 182.
} 
The scope of this article is limited to price regulation in the context of transaction between private contracting parties. It does not cover administrative service charges, and tariffs and charges applied by stateowned enterprises with natural monopoly. The first section deals with theoretical overview and different manifestations of price regulation from the political-economy perspective; and Section 2 focuses on undesirable consequences of price regulation. The third section examines the various laws and subordinate instruments regulating prices including their constitutional basis and internal consistency. Section 4 briefly discusses some of the major efforts to regulate prices in Ethiopia (by focusing on the nexus between the law and the practice), followed by conclusions.

\section{A Brief Overview of the Politico-Economic Analysis of Price Regulation}

\subsection{Price regulation and the free market}

Price control is inherently connected with freedom of contract, and as such interferes with the freedom of contract of the parties involved in a transaction subjected to price regulation. The "right to contract implies that the resources involved are, at least to some degree, exclusively owned" by the contracting parties. ${ }^{2}$ If that is the case, prices should naturally be the function of supply and demand. It should be remembered that "demand and supply schedules are conceptual tools which restrict the maximum quantities of a good individuals are willing to buy or sell at varying prices."”

In a system of free market, prices play two important functions: promoting efficiency and signaling key market tendencies. For instance, "assuming a degree of substitutability between products or services, price is the most immediate parameter upon which undertakings compete" with each other. ${ }^{4}$ Secondly, "the price formation process generates signaling effects which facilitate efficient behavior. High prices suggest that demand outstrips supply, which indicates that a market is profitable and invites entry-which, other things being equal, should lower prices due to increased competition." ${ }^{, 5}$

\footnotetext{
2 Steven N. S. Cheung (1974), 'The Theory of Price Control' The Journal of Law \& Economics, Vol. 17, No. 1, p. 56.

${ }^{3}$ Id, p. 54.

${ }^{4}$ Niamh Dunne (2017), 'Price Regulation in the Social Market Economy', LSE Law, Society and Economy Working Papers No.3, published by the London School of Economics and Political Science Law Department, p. 4.

${ }^{5}$ Ibid.
} 
Concomitantly, increasing price forces consumers to decide upon the extent to which they value a good or service and, in theory, "result in that scarce commodity being allocated to those who value it the greatest. In this manner, the price formation mechanism leads to an efficient distribution of society's finite resources. ${ }^{\prime 6}$

Therefore, while the determination of "market prices through the dynamic interaction of supply and demand is the basic building block of economics", the interference of governments through price control distorts this basic order. Fiona Morton puts this interaction as follows:

Consumer preferences for a product determine how much of it they will buy at any given price. Consumers will purchase more of a product as its price declines, all else being equal. Firms, in turn, decide how much they are willing to supply at different prices. In general, if consumers appear willing to pay higher prices for a product, then more manufacturers will try to produce the product, will increase their production capacity, and will conduct research to improve the product. Thus, higher expected prices lead to an increased supply of goods. This dynamic interaction produces an equilibrium market price; when buyers and sellers transact freely, the price that results causes the quantity demanded by consumers to exactly equal the supply produced by sellers. ${ }^{7}$

However, "when government adopts a price control, it defines the market price and forces ... transactions to take place at that price instead of the equilibrium price set through the interaction between supply and demand." 8 On the other hand, while "supply and demand shift constantly in response to tastes and costs, but the government price will change only after a lengthy political process, the government price will effectively never be an equilibrium price. This means that the government price will be either too high or too low." There are two serious problems that result from prices imposed in this way. On the one hand, higher prices imposed by the government trigger more supply than what consumers want or can afford, eventually giving rise to wastage. In the developed world, government purchase of agricultural products with the view to increasing farmers' income has created this type of dysfunction. In contrast, lower prices set by the government make consumers to want more of the product than what is

\footnotetext{
${ }^{6}$ Ibid.

${ }^{7}$ Fiona M. S.Morton (2001), 'The Problems of Price Controls Regulation' Cato Review of Business and Government, Vol. 24, No. 1, p. 2

${ }^{8}$ Ibid.

${ }^{9}$ Ibid.
} 
made available by producers. ${ }^{10}$ However, the lower price discourages production and ultimately results in scarcity.

Part of the reason why governments resort to price control is a wrong understanding of the very notion of price itself. Christopher Coyne and Rachel Coyne sum up this problem as follows:

Prices are a commonly misunderstood concept. Many view prices as random numbers assigned by a seller. Related to this, many see prices as being an impediment to accomplishing their desired goals. The view of prices as impediments to achieving one's goals is one reason why there are so often calls for politicians and regulators to place controls on prices. The belief, from the perspective of proponents of price controls, is that, if regulators impose controls, then people will be able to achieve goals that would otherwise be unachievable. For example, in order to assist younger citizens with their cost of living, a politician may propose some combination of rent controls and a living wage to make cities ... more affordable. These views, however, misconstrue the fundamental nature and role that prices play in an economic system. ${ }^{11}$

Price control has been placed on various sectors of the economy, including basic consumer commodities, energy, wage, rent and transport fares, to name just a few. From the comparative perspective, unlike the conventional view that price regulation is the hallmark of developing countries, or undemocratic political systems, it pervades across all economies and ideologies. ${ }^{12}$ Indeed, "the use of price controls by governments has a long history spanning thousands of years;" and historically, "the notion that there is a 'just' or 'fair' price for a certain commodity, a price which can and ought to be enforced by government, is apparently coterminous with civilization." ${ }^{33}$ For example, in ancient Babylon, "some forty centuries ago, the Code of Hammurabi, the first of the great written law codes, imposed a rigid system of controls over wages and prices." 14 Several centuries later, the Roman Empire, "imposed price controls to attempt to combat inflation due to the debasement of currency." 15

\footnotetext{
${ }^{10} \mathrm{Id}$, p. 6.

${ }^{11}$ Christopher J. Coyne and Rachel L. Coyne, Editors (2015), Flaws and Ceilings: Price Controls and the Damage They Cause (The Institute of Economic Affairs) p. 8.

${ }^{12}$ See generally, Robert L. Schuettinger and Eamonn F. Butler (2002), Forty Centuries of Wage and Price Controls: How Not To Fight Inflation (The Heritage Foundation)

${ }^{13}$ Id, p. 9.

${ }^{14} \mathrm{Id}$, p. 11.

${ }^{15}$ Christopher Coyne and Rachel Coyne, supra note 11, p. 1.
} 
Later on, medieval kingdoms, and $19^{\text {th }}$ century states had exercised price control.

Likewise, the $20^{\text {th }}$ century western economies are not immune to price control intervention. Hence, "the US government imposed price controls during both world wars, as well as during the Korean War, with the goal of rationing items deemed as necessary by the government." 16 Moreover, Coyne recalls that "both the UK and US governments implemented general wage and price controls in the 1970s. In 1971, President Nixon famously imposed wage and price freezes for a ninety day period to combat inflation." 17

As indicated above, the use of price control has primarily political and economic motives, and too infrequently it has social objectives such as determination of floor prices to discourage addiction in alcohol and tobacco use. ${ }^{18}$ However, price regulation achieves the social objectives more often, while it may sometimes achieve the political gains and rarely attains the economic objectives. The political gain that price control creates is increasing political support for the incumbent politicians. However, from economic point of view, "the implementation of price controls does not change the fundamental nature of the economic problem. Decisions still need to be made about how to best allocate scarce resources among an array of feasible alternatives." 19 Where price controls do not apply, "these decisions are made through the market process, which relies on true market prices reflecting the relative scarcity of resources. However, with the implementation of controls, the market process is distorted and political competition, at least partly, replaces market competition." 20

In the case of minimum wages, the effect of these measures has been reported as negative. According to Christopher and Rachel Coyne:

Setting minimum wages is easy, but this deals with the symptoms of low pay and not the causes. The political payoff from minimum wage laws is immediate: the dispersion of wages is reduced and, since more women are low paid, so is the difference between male and female average pay. Yet nothing is done about the real problems in the labor market and the education system. The low level of skills acquired by children from our many single-parent families is ignored, as is the worklessness among

\footnotetext{
${ }^{16} \mathrm{Id}$, p. 2.

${ }^{17} \mathrm{Id}$, p. 2.

${ }^{18}$ See below section 2.2.1

${ }^{19}$ Christopher Coyne and Rachel Coyne, supra note 11, p. 23.

${ }^{20}$ Ibid.
} 
these families. As for really disadvantaged groups such as the disabled, the minimum wage may do much harm. The best that can be said of the minimum wage policy is that it is irrelevant to real problems of inequality and worklessness. More likely, it is part of a package combined with other floors on working conditions which make matters worse. ${ }^{21}$

The economic motivation behind price regulation can be equally, if not more, sinister as that of the political in certain instances. The underlying source for the economic motivation drives from the nature of the state and its monopoly of police power. Inherently, "the state has one basic resource which in pure principle is not shared with even the mightiest of its citizens: the power to coerce. The state can ordain the physical movements of resources and the economic decisions of households and firms without their consent." 22

Thus, two of the major public resources commonly sought by an industry are control over entry by new rivals, and price fixing. ${ }^{23}$ Price fixing by government is a key public policy decision sought by an industry for creating and maintaining economic dominance. In reality, "even the industry that has achieved entry control will often want price controls administered by a body with coercive powers. If the number of firms in the regulated industry is even moderately large, price discrimination will be difficult to maintain in the absence of public support." 24 This is because "price control is essential to achieve more than competitive rates of return" and is the easiest way. ${ }^{25}$

This does not mean that governments do not employ price regulation as a genuine means of dealing with economic problems such as inflation and shortage of supply. Such solutions, however benign in design, are ineffective in resolving these problems. Robert Schuettinger and Eamonn Butler explored data on the problem of inflation and the role of price control in solving the problem in different societies over four thousand years, and state their findings as follows:

${ }^{21}$ W.S. Siebert (2015), 'The Simple Economics of Wage Floors' [in Christopher J. Coyne and Rachel L. Coyne, Editors, (2015), Flaws and Ceilings: Price Controls and the Damage They Cause (The Institute of Economic Affairs) p. 47.

${ }^{22}$ George J. Stigler (1971), 'The Theory of Economic Regulation', The Bell Journal of Economics and Management Science, Vol. 2, No. 1, p. 4.

${ }^{23}$ Id, p. 5.

${ }^{24}$ Id, p. 6.

${ }^{25}$ Ibid. 
What, then, have price controls achieved in the recurrent struggle to restrain inflation and overcome shortages? The historical record is a grimly uniform sequence of repeated failures. Indeed, there is not a single episode where price controls have worked to stop inflation or cure shortages. Instead of curbing inflation, price controls add other complications to the inflation disease, such as black markets and shortages that reflect the waste and misallocation of resources caused by the price controls themselves. Instead of eliminating shortages, price controls cause or worsen shortages. ${ }^{26}$

The history of price regulation from Hammurabi, to ancient Egypt, to Sumeria, to Rome, Medieval England, French Revolution to modern day America and Ethiopia, invariably shows that price controls never worked to control inflation. ${ }^{27}$ From the economic point of view price controls naturally distort basic supply and demand relationships. Giving signals of 'low prices' to producers limits supply; and 'low' prices to consumers stimulate demand; and price controls widen the gap between supply and demand. ${ }^{28}$ Exceptionally, "price caps may be justified when there is clear evidence that an organization is exploiting market power, though a better corrective is to undermine that market power by removing barriers to entry to the relevant activity." 29

\subsection{Forms of price controls}

Price regulation is designed and enforced in many different forms. The most prominent forms of price regulation, discussed below, are setting floor prices, ceiling prices and control of margins of profits.

\subsubsection{Floor prices}

Floor price is a typical form of price control which makes payment of a price below the floor illegal. The most prominent example of floor price is the minimum wage in most developed countries. When in force, "a wage floor such as the minimum wage makes payment of low wages illegal."30 Apart from minimum wages, floor pricing is sometimes used to dampen unhealthy competition when free market competition leads to race to the bottom.

\footnotetext{
${ }^{26}$ Robert L. Schuettinger and Eamonn F. Butler, supra note 12, p. 3.

${ }^{27}$ See, ibid.

${ }^{28}$ Id, p. 4.

${ }^{29}$ Colin Robinson (2015), 'Energy Price Caps', [in Christopher J. Coyne and Rachel L. Coyne, Editors, (2015), Flaws and Ceilings: Price Controls and the Damage They Cause (The Institute of Economic Affairs) p. 98]

${ }^{30}$ W.S. Siebert, supra note 21, p. 45
} 
"From the view point of traditional theory, the introduction of price floors ... protects competitors from making zero profits, and should thus be anticompetitive." ${ }^{31}$ However, in certain situations the presence of price floors can foster healthy competition and lead to more competitive pricing. ${ }^{32}$

Another area of floor price is the minimum unit pricing in alcohol pricing in Europe. In England, the minimum unit pricing (MUP) of alcohol, i.e., a floor price below which retailers cannot sell a unit of alcohol has been a topic of debate for some time. ${ }^{33}$ Contrary to other types of price controls MUP on alcohol is said to be effective in controlling alcoholism, and has been considered a better policy than tax mechanisms. Proponents of the policy contend that "minimum pricing is preferable to tax rises because it directly targets the cheapest alcohol that tends to be bought by the heaviest drinkers"; and they argue that "tax rises are frequently not passed on to the customer because the drinks industry absorbs the costs." ${ }^{34}$ Indeed, studies in various countries have shown that high floor prices have an impact of reducing alcohol consumption, thereby becoming an important public health policy instrument. ${ }^{35}$ On the contrary, "opponents of the policy argue that cheap alcohol is disproportionately purchased by people on low incomes and that MUP is therefore discriminatory and regressive." 36

Likewise, floor prices have helped many countries to control the problem of smoking and tobacco use. ${ }^{37}$ Interestingly, thus, price regulation in the

${ }^{31}$ Martin Dufwenberg et al (2007), 'Price floors and competition', Economic Theory, 33: 211-224, p. 220.

${ }^{32}$ Ibid.

${ }^{33}$ Christopher Snowdon (2015), 'Minimum Unit Pricing' [in Christopher J. Coyne and

Rachel L. Coyne, Editors, (2015), Flaws and Ceilings: Price Controls and the Damage They Cause (The Institute of Economic Affairs) p.177]

${ }^{34}$ Ibid.

${ }^{35}$ Tim Stockwell1, et al, Does minimum pricing reduce alcohol consumption? The experience of a Canadian province, available at $<$ https://onlinelibrary.wiley.com/doi/epdf/10.1111/j.1360-0443.2011.03763.x.> Accessed, 10 Sept. 2019; Tim Stockwell, and Gerald Thomas, Is alcohol too cheap in the UK? The case for setting a Minimum Unit Price for alcohol, An Institute of Alcohol Studies Report, 2013, Available at $<$ http://www.ias.org.uk/uploads/pdf/News\%20stories/iasreport-thomas-stockwellapril2013.pdf $>$ Accessed, 10 Sept. 2019.

${ }^{36}$ Christopher Snowdon, supra note 33, p. 178

${ }^{37}$ Nigel Rice et al, 'Systematic Review of the Effects of Price on the Smoking Behavior of Young People', PHR Public Health Research Consortium p. vii, Available at 
form of price floors can be effective. However, this efficacy relates to solving social than the economic problem. Ethiopia does not use floor prices on tobacco and alcohol; and has rather chosen the taxation mechanism, namely, the excise tax law. While the impact of alcohol and tobacco on public health may not warrant price policy intervention in Ethiopia at present ${ }^{38}$ the absence of direct floor pricing in any sector in Ethiopia is notable. ${ }^{39}$ The only law that allows determining price floor is Insurance Business (Amendment) Proclamation No. 1163/2019 in relation to insurance premiums. It calls for NBE to issue a directive fixing minimum insurance premium; but the directive has not yet been introduced. The provision in Trade Competition and Consumer Protection Proclamation that prohibits selling below production cost can be taken as an indirect minimum price determination, but it is more of a principle than a direct floor fixing by the regulator. ${ }^{40}$

\subsubsection{Price ceilings}

Contrary to price floors, "a price ceiling is a legally mandated price that is set below the equilibrium price" introduced to avert unwanted price

$<$ http://phrc.lshtm.ac.uk/papers/PHRC_A2-06_Final_Report.pdf $>$ Accessed 6 Sept. 2019.

38 According to 2015 data from Tobacco Atlas, in Ethiopia $6.2 \%$ of male adults, $0.2 \%$ female adults, $0.2 \%$ boys and $0.08 \%$ of girls use tobacco on daily basis; while tobacco accounts for $3.8 \%$ male and 1.02 female deaths in Ethiopia. (available at, $<$ https://files.tobaccoatlas.org/wp-content/uploads/pdf/ethiopia-country-facts-en.pdf $>$ Accessed, 20 Sept. 2010) These numbers are comparably low in contrast to for Example Kenya and UK. In Kenya $14.9 \%$ of adult male, and 0.51 of adult females consume tobacco on daily basis, while tobacco accounts for $4.22 \%$ overall deaths. (Available at $<$ https://tobaccoatlas.org/country/kenya/> Accessed, 20 Sept. 2010). In the UK on the other hand, $19.9 \%$ of adults smoke Tobacco while the prevalence of tobacco use with children shows $1.94 \%$ users. In the UK tobacco accounted for $20.55 \%$ deaths for the same period. Available at:

$<$ https://tobaccoatlas.org/country/united-kingdom/ Accessed, 20 Sept. 2010].

In relation to Alcohol, The UK registers 11.4 liters of pure alcohol use per capita, while Kenya $3.4 \%$ while Ethiopia still shows lower rate of alcohol use at $2.8 \%$ of pure alcohol use per capita. Available at $<$ https://ourworldindata.org/grapher/totalalcohol-consumption-per-capita-litres-of-pure-alcohol?time=earliest..latest $>$ Accessed, 20 Sept. 2010.

${ }^{39}$ This writer could not find any instance of floor prices in Ethiopia in practice. There is, however, a new proclamation empowering the NBE to issue floor premium rate. See 'Insurance Business (Amendment) Proclamation No. 1163/2019, Federal Negarit Gazetta, Year 26, No. 6, January 2020, Article 58.'

${ }^{40}$ See Section 3.4 below. 
increase ${ }^{41}$ It is argued that, "a price below the equilibrium price will result in a shortage where consumers demand more than producers are willing to supply." ${ }^{2}$ In practice, many sectors are often prone to price ceiling, namely rent, wage, fuel and commodities.

While many countries have detailed legislation regulating tenant-landlord relationships, rent control is a special type of regulation. There are various forms of rent control, but they all take the character of legally imposed below-market rates for rental housing. ${ }^{43}$ The other sector where price cap is applied is in energy market. In almost all countries "price controls have often been applied in energy markets, whether under state or private ownership, by legislators or by government-appointed regulators." 44 Given the politically sensitive nature of fuel prices, and the internationalization of price determination, capping of fuel prices has been taken for granted in many jurisdictions.

Price capping is also applied on food items, cereals, etc., that are used for production of food stuff. Perhaps, food price ceiling may be one of the oldest of price regulation in the world. ${ }^{45}$ In ancient Rome, for instance, Emperor Diocletian introduced a long list of food items with corresponding prices, punishing any breach with the death penalty. ${ }^{46}$ Food price ceiling has thus become an important policy instrument in many countries especially for developing countries like Ethiopia. ${ }^{47}$ In more developed countries, a typical item often chosen for price capping is medicine. Many countries like France $^{48}$, Germany ${ }^{49}$ and the $\mathrm{UK}^{50}$ apply some level of price regulation on

${ }^{41}$ Christopher Coyne and Rachel Coyne, supra note 11, p. 17.

${ }^{42}$ Ibid.

${ }^{43}$ Fiona M. Scott Morton, supra note 7, p. 5.

${ }^{44}$ Colin Robinson, supra note 29, p. 96.

${ }^{45}$ Robert L. Schuettinger and Eamonn F. Butler, supra note 12, p. 20.

${ }^{46}$ Ibid.

${ }^{47}$ Peter Timmer (1989), Food Price Policy: The Rationale of Government Intervention, (Butterworth \& Co Publishers) p. 21.

${ }^{48}$ OECD (2018), Pharmaceutical Reimbursement and Pricing in Germany, OECD Better Policies for Better Life, Available at: $<$ https://www.oecd.org/health/healthsystems/Pharmaceutical-Reimbursement-and-Pricing-in-Germany.pdf $>$ Accessed, 6 Sept. 2019.

${ }^{49}$ Nathalie Grandls (2008), Drug Price Setting and Regulation in France, Available at $<$ https://www.irdes.fr/EspaceAnglais/Publications/WorkingPapers/DT16DrugPriceSet tingRegulationFrance.pdf $>$ Accessed, 6 Sept. 2019.

${ }^{50}$ Charlotte Tillet et al, The UK Pharmaceutical Pricing Landscape, S\&B Stevens and Bolton LLP, Available at: $<$ https://www.stevens- 
drugs. However, "unlike the practice in many countries, Ethiopia does not regulate the price of medicine." 51

\subsubsection{Profit margin control}

Regulation of profit margin, also known as mark-up regulation is another type of price control mechanism less known and less used than ceiling and floor control. Conceptually, "a mark-up may be defined as the difference between the purchase price (cost price) and the selling price of a commodity." 52 In other words, a mark-up represents the additional charges and the costs which are applied in order to cover overhead costs, distribution charges, and a profit may also be described as the 'gross profit'. ${ }^{53}$ Various jurisdictions have used profit margin regulation as an alternative to floor and ceiling control or as supplementary to price control. ${ }^{54}$

Though mark-up regulation is highly related with price caps, it differs from price ceiling in a number of ways. "First, it constrains firms (or products) with higher markups, which are not necessarily those with higher prices. Hence, the impact of markup regulation on the distribution of prices will generally differ from that of price ceilings." 55 Secondly from the economic point of view, "markup regulation limits the benefits from cost reductions, while price regulation provides strong incentives to increase efficiency." 56

Mark-up regulation is often used in regulating the price of pharmaceuticals in many developed and middle income countries. ${ }^{57}$ Apart

bolton.com/cms/document/Spotlight_on_pharmaceutical_pricing_regulation.pdf $>$ Accessed 6 Sept. 2019.

${ }^{51}$ Fikremarkos Merso (2017), Patents and the Development of the Pharma Industry, Ethiopian Civil and Commercial Law Series, Vol 7, p. 157

${ }^{52}$ The Regulation of Mark-ups in the Pharmaceutical Supply Chain, WHO/HAI Project on Medicine Prices and Availability, 2011, p. 1, Available at<https://haiweb.org/wpcontent/uploads/2015/07/Working-Paper-3-Regulation-of-Mark-ups.pdf $>$ Accessed, Sept. 4, 2019.

${ }^{53}$ Ibid.

${ }^{54}$ John Sheahan (1961), 'Problems and Possibilities of Industrial Price Control: Postwar French Experience', The American Economic Review, Vol. 51 No.3, p. 347.

${ }^{55}$ Christos Genakos et al, The Impact of Maximum Mark-up Regulation on Prices, 2015, p. 6, Available at:

<http://www2.aueb.gr/users/cgenakos/Research.files/GKP_Markup\%20regulation.pd f $>$ Accessed 4 Sept. 2019.

${ }^{56}$ Ibid.

${ }^{57}$ See generally, The Regulation of Mark-ups in the Pharmaceutical Supply Chain, supra note 52. 
from medicines, markup regulation is used in fruits and vegetables markets in which price cap would be impossible to implement due to high seasonality or uncertainty in production costs. ${ }^{58}$ From the administrative point of view, "the enforcement of markup regulations is generally more difficult and costly as firms may misreport or distort their cost structure in response to regulation." 59 This may be the reason behind the reluctance of Ethiopian authorities to use profit margin control in regulating prices.

\section{Undesirable Consequences of Price Regulation}

It should be clear from the foregoing discussion that price regulation is a measure taken only when an economy is in an unhealthy state. It is a strong pill prescribed for a serious economic pathology, and as such carries its own side effects. There has not been agreement in spite of the numerous investigations carried out over centuries as to whether the adverse effects outweigh the positive impacts of price regulation. ${ }^{60}$ Apart from inability to bring about reduction in prices, price controls have resulted in distorting competition, and causing scarcity which in turn encourages an underground market. $^{61}$

Economic analysis of effects of price regulation seems to invariably suggest that price regulation is doomed to fail in terms of achieving economic objectives. The basic supply and demand framework highlights the fact that, in an unhampered market, there is an "inherent tendency for prices to adjust to align the different interests of consumers and suppliers. This is an ongoing and continual process, which is precisely why unregulated prices are so important. ${ }^{.62}$ This is mainly because, prices respond to the context-specific realities facing individual consumers and suppliers. Indeed, "these individuals do not have to have any working knowledge of economics or the market process but they act as if they do precisely because prices provide information and profit and loss provides the incentive to act on that information." 63 Hence, "from an economic standpoint, price controls are problematic because they distort the price

\footnotetext{
${ }^{58}$ Christos Genakos et al, supra note 55, p. 6.

${ }^{59}$ Ibid.

${ }^{60}$ See generally, Robert L. Schuettinger and Eamonn F. Butler, supra note 12.

${ }^{61}$ John Sheahan, supra note 54, p. 352.

${ }^{62}$ Christopher Coyne and Rachel Coyne, supra note 11, p. 15.

${ }^{63}$ Ibid.
} 
mechanism's ability to allocate resources to their highest-valued uses through voluntary exchange."64

Price controls in the form of caps usually create underground markets where only some actors (suppliers or consumers) benefit from the price while the majority suffers. A price cap encourages an underground market where the price-controlled good is sold at a price above the cap, anyway, but only to some who can afford. This in turn discourages innovation; denies incentive for quality improvement. ${ }^{65}$ In the pharmaceuticals sector, price regulation has been shown to have a negative effect of discouraging investment and innovation in medicines. As researches indicate, the "examination of the relationship between sales growth and innovation growth in the industry demonstrates that increasing sales increases innovation in the industry." 66 Especially in the pharmaceuticals sector, "an understanding of the link between sales and innovation is crucial given the long drug discovery process and the limited life of patents." 67

In the real estate sector the negative consequences of price control have been well documented. For instance, the simple controls on rents introduced in many Western countries following World War II, to prevent alleged profiteering by landlords proved "more difficult to abolish than to implement." These 'first-generation' 'rent ceilings' only created shortages of rental accommodation, with many other negative unintended consequences. ${ }^{68}$ According to one study;

This shortage leads to a host of related distortions. For example, since there is a queue of people willing to rent each apartment and landlords are not permitted to discriminate based on price, the landlords will discriminate on whatever characteristic they please. Landlords may also ask for under-the- table payments from tenants or require renters to hand over an initial fee in order to sign the lease. Moreover, landlords have little incentive to maintain apartments; it is more difficult to recoup the cost of improvements through the government-established price and, at the same time, there is a strong demand for apartments regardless of their condition. Consequently, the quality of housing stock declines and the

\footnotetext{
${ }^{64}$ Ibid.

${ }^{65} \mathrm{Id}, \mathrm{p} .16$.

${ }^{66}$ Jennifer L. Troyer and Alexander V. Krasnikov (2002), 'The Effect of Price Regulation on Innovation in the Pharmaceutical Industry', Journal of Applied Business Research, Vol. 18 No.4, p. 94.

${ }^{67}$ Ibid.

${ }^{68}$ W.S. Siebert, supra note 21, p. 72.
} 
area may only attract less affluent residents. This hurts neighborhood businesses. New housing stock is less profitable to construct if government controls rental prices; thus fewer investors will engage in that activity and economic development will slow. ${ }^{69}$

On top of these, price regulation has drawback from the administrative point of view. First and foremost, fixing the regulatory price is a daunting task. The regulating entity must be certain that business entities have incentives to comply, while ensuring at the same time that profits are neither excessive nor unviable. Given the inherent politicization of the endeavor, it is often impossible to be precise. Thus, price controls can have unintended negative consequences, such as moral hazard, rent seeking, inefficient subsidies, or distortion of optimal supply and demand levels. Regulatory lag may also arise, whereby delays in responding to "new market conditions render the regulated price increasingly inappropriate. Indiscriminate application of pricing controls might furthermore damage corporate incentives to invest, thus leading to a diminution in innovation and a reduction in overall consumer welfare." ${ }^{\prime 70}$

Generally, price controls distort competition, and encourage illicit trade. Price ceilings also discourage investment in research, development and innovation and ultimately result in lower quality of goods and services in the market. This, in turn, leads to lower consumer welfare. Lower price ceilings on the other hand encourage demand, which along with decreasing supply leads to underground markets for such commodities at higher prices than the one fixed by the regulator. ${ }^{71}$

\section{The Law on Price Regulation in Ethiopia}

\subsection{Price regulation versus property rights}

There is some tendency to associate price regulation with expropriation borrowing the concept of regulatory expropriation from international law. ${ }^{72}$ However, even in international law, it is hard to find authority where price regulation is conclusively declared as an equivalent of expropriation. There

${ }^{69}$ Fiona M. Scott Morton, supra note 7, p. 5.

${ }^{70}$ Ibid.

${ }^{71}$ Seid Hassan (2011), 'The Futile and Damaging Effect of Ethiopian Price Caps', Available at: $<$ https://www.ethiox.com/articles/Ethiopian_\%20Price_Caps.pdf $>$ Accessed 28 August 2019.

${ }^{72}$ See for instance, William A. Fischel (1991), 'Exploring the Kozinski Paradox: Why Is More Efficient Regulation a Taking of Property', 67 Chicago Kent Law Review. 
are cases where the denial of price stabilization measure to an investor on account of governmental price control was submitted to a tribunal contending that it amounted to an indirect expropriation. But the submission was denied. ${ }^{73}$

Of the many jurisdictions where price control is debated, the USA appears to be the place where it is discussed in the light of expropriation/takings law. In the USA, the characterization of price control has been a subject of controversy in the academia and in the courts for a long time. $^{74}$ Thus, US Courts have gradually developed three criteria in the context of the constitution's takings protection, namely, that (i) the price control should be for public interest; (ii) the price control should not be temporary; and (iii) the investor's exit from the price-controlled business should be possible. ${ }^{75}$

As the first two criteria are clear, the last one has been explained in a two-pronged test: the legal obligation theory and the specific capital theory. ${ }^{76}$ According to the legal obligation theory, "price controls present a Takings Clause issue only when someone is subject to a legal obligation to devote their product or services to the public use."77 The idea is that, in the absence of such a legal obligation, the individual/business is free to shift its activities to a sector free from price control. The specific capital theory on the other hand, looks at the economic possibility, not the legal, of shifting to a sector free of such control. Here, the "question is whether a person has invested capital in a price-controlled market that has no value, or at best a substantially reduced value, in any alternative use." ${ }^{\text {"78 }}$

As a result of these judicial interpretations of the takings clause, US courts have come to distinguish between price controls in the utility sector on the one hand, and general price control legislation on the other. ${ }^{79}$ As Drobak noted, "the Supreme Court has consistently ruled over the past one hundred years that utility rate making is a governmental taking that triggers

${ }^{73}$ Rabia Cihan Aydogan (2011), 'State Measure Affecting the Property of Foreign Investors: Expropriation or Regulation', Ankara Bar Review, 2011/2, p. 144.

${ }^{74}$ John N. Drobak (1986), 'Constitutional Limits on Price and Rent Control: The Lessons of Utility Regulation' Washington University Law Review, Vol. 64, Issue 1, p. 108.

${ }^{75} \mathrm{Id}, \mathrm{p} .110$.

76 Thomas W. Merrill (1994), 'Constitutional Limits on Physician Price Controls', 21 Hastings Const. L.Q. p. 639.

${ }^{77}$ Ibid.

${ }^{78}$ Ibid.

${ }^{79}$ John N. Drobak, supra note 74, p. 108. 
the compensation requirement" in the Constitution. ${ }^{80}$ Since utility companies cannot withdraw as of right, they qualify for the constitutional protection enshrined in the takings clause. This is because "the statutes require utilities to continue providing service until they obtain permission to cease." ${ }^{\prime 1}$ Besides, legal barriers to exit, "a firm's investment in specialized assets, which cannot be easily converted to other uses, can make exit from price controlled business or market almost as infeasible". ${ }^{82}$ Investment of utility service providers such as electricity transmission infrastructure, water transmissions lines, telecom towers, and masts, etc can have little or no alternative use. Hence, utility price regulation is often regarded in the USA as expropriation; while other price regulation acts are not.

Under Ethiopian law, Article 40 of the Constitution protects private property. The definition of private property under Article 40(2) encompasses goods and services of business firms. Article 40(1) establishes the basic principle of protection of private property stating that, private property is protected, and "unless prescribed by law on account of public interest, this right includes the right to acquire, to use and, and in a manner compatible with the rights of other citizens to dispose of such property by sale or bequest or to transfer it otherwise." ${ }^{, 3}$

However, the characterization of price regulation as an indirect expropriation seems to be untenable under the Ethiopian Constitution. There is not a single case where price regulation was challenged before a court of law, let alone one where the expropriation clause of the Constitution was addressed. For the Constitution, expropriation takes place only if government takes private property. Since, the concept of indirect expropriation does not exist in Ethiopia, ${ }^{84}$ one cannot say that the protections enshrined in the Constitution against expropriation can readily be applied in

\footnotetext{
${ }^{80} \mathrm{Id}$, p. 109.

${ }^{81} \mathrm{Id}$, p. 120.

${ }^{82} \mathrm{Id}, \mathrm{p} .111$.

${ }^{83}$ Art. 40(1) of Constitution of the Federal Democratic Republic of Ethiopia Proclamation No. 1/1995, $1^{\text {st }}$ Year, No. 1, 21 August 1995 (hereinafter FDRE Constitution).

${ }^{84}$ See, Hailemariam Belay, Indirect Expropriation under the Ethiopian Law: Questing for its Recognition under Domestic Investment Laws and Its Implications, LL.M Thesis, Mekele University School of Law, (2019) p.99. available at: $<$ https://www.academia.edu/41344675/_Indirect_Expropriation_under_the_Ethiopian _Law_Questing_for_Its_Recognition_under_Domestic_Investment_Laws_and_It_Im plications._>, accessed on 24 April 2020.
} 
cases of price regulation, however arbitrary and damaging the regulation may be. This does not, however, mean that price regulation should remain unreviewable; nor does it mean that it should not be subjected to clear standards. Or else, it will be no more than an instrument of populist politicians who promote unviable remedies for the masses at the expense of businesses.

\subsection{The Constitutional basis of price regulation in Ethiopia}

Arguably, the constitutional basis for governmental authority to regulate prices under Ethiopian law stems from the State's policy making power under Article 51 and the economic objectives expressed under Article 89. The powers embodied under Article 51 give the Federal Government the power to formulate economic policies (51/2), transport regulation (51/9), and interstate commerce power (51/12). And the powers stated in Article 89 are the ones stated under sub-paragraphs 3 and 8 . Article 51 of the Constitution lists powers and functions of the federal government, and thus lays down the legislative power of the Federal State in respect of formulation and implementation of economic policies (sub-paragraph 2), development, administration and regulation of air, rail, water way and sea transport and major roads linking two states (sub-paragraph 9), and regulation of interstate commerce (sub-paragraph 12). All these provisions can somehow be invoked as the source of regulatory power of the state. There might be overlap between sub-paragraph 9 and 12 when it comes to price regulation. However, all these powers can serve as a basis for price regulation.

While the powers under Article 51 define the State's policy making power in concrete terms, the provisions of Article 89 are guiding principles in the exercise of these defined powers. Thus, any uncertainty surrounding price control power under Article 51 is easily dispelled when one looks at the overarching policies and objectives that should guide the exercise of powers under Article 51. For instance, Article 89(8) states that "government shall endeavor to protect and promote the health, welfare and living standards of the working population of the country." Price regulation being often portrayed as a pro-poor regulatory intervention, this principle can serve as a very powerful justification.

The other constitutional basis for price regulation can be state of emergency provisions under the Constitution. Price control can be used as a state of emergency power where natural disaster or epidemic occurs in terms of Article 93 of the Constitution. ${ }^{85}$ Natural disasters such flooding, drought,

\footnotetext{
${ }^{85}$ Article 93 of FDRE Constitution, supra note 83.
} 
and locust invasion may bring about food shortage that may require price control and rationing. Likewise, the outbreak of a nationwide epidemic may result in price control of medicines and medical services, if not control of basic food items. Epidemic can trigger scarcity as it debilitates the productive capacity, transportation, and processing industries.

Such interventionist measures can be justified on grounds that during such emergencies "the ordinary laws of economics cannot cope with such an unnatural situation. Price remains no longer a deterrent to demand for either goods or services. The result is an ever spiraling inflation." 86 Due to the natural [or unnatural] scarcity, consumers will be forced to demand irrespective of the price increase, and price will no more serve its natural function of defining the equilibrium between supply and demand. In the absence of such price control, the main groups who suffer the most (in such circumstances) will be those who have fixed income, such as employees. ${ }^{87}$ Again, if the provisions of Article 93 that define state of emergency power are uncertain on the constitutionality of price control, Article 89 comes to its aid.

The criticism against price regulation loses its force in such circumstances. During emergencies, the positive effects of price controls could offset the drawbacks. Price controls "may be necessary so that some unscrupulous individuals could not use the sudden and unexpected situations to create big windfall gains for them while hurting so many others. Temporary price controls could also be effective in managing the country's reserves, such as to buy time until the reserves are put into the supply networks." $" 88$

Emergency price controls can be justified in the services sector as well. For example, a statement on the website of the Federal Transport Authority (listing its powers) indicates that "in case of natural disasters or temporary economic or social crisis, the Authority can compel commercial road transport vehicles to operate in areas and routes where their services are demanded in accordance with directives given by the Government." ${ }^{\prime 9}$ Even though there is no reference for price determination in the statement, it

\footnotetext{
${ }^{86}$ Bernard F. Grainey (1943), 'Price Control and the Emergency Price Control Act', Notre Dame Law Review Vol. 19, Issue 1, p. 31.

${ }^{87}$ Ibid.

${ }^{88}$ Seid Hassan, supra note 71.

${ }^{89}$ See Powers and Duties of the Authority available at:

$<$ http://www.rta.gov.et/home.htm\#when> Accessed 18 August 2019.
} 
is obvious that the directive envisaged in the website will come with price control. Otherwise, transport providers can frustrate the emergency management by quoting excessive prices. The statement seems to be inspired by Article 4(1)(1) of Proclamation 468/2005. ${ }^{90}$ It states that the Authority shall "follow up that persons and individuals engaged in public commercial road transport in case of market failure or the public faces transport shortage and ensure the compliance of transport service supply and demand at national level as well as make the trip equitable."

War is another emergency situation that necessitates regulatory intervention in the market. The US experience shows that the US government can exercise unfettered power in times of war, under the war clause:

This power is tremendous; it is strictly constitutional; but it breaks down every barrier so anxiously erected for the protection of liberty, property and of life. To the end that war may not result in defeat, freedom of speech may, by act of Congress, be curtailed or denied so that the morale of the people and the spirit of the army may not be broken by seditious utterances; freedom of the press curtailed to preserve our military plans and movements from the knowledge of the enemy; deserters and spies put to death without indictment or trial by jury; ships and supplies requisitioned; property of alien enemies, heretofore under the protection of the Constitution, seized without process and converted to the public use without compensation and without due process of law in the ordinary sense of that term; prices of food and other necessities of life fixed or regulated. ${ }^{91}$

In Ethiopia, the constitutional provision that refers to external invasion in Article 93 is clearly a power with the potential to encompass and justify price controls. Generally, therefore, all the grounds for state of emergency under Article 93(1)(a) of the Constitution can be used as alternative basis of price control by the federal government. Likewise, regional states can use Article 93(1)(b) to control prices in emergencies caused by region wide natural disasters and epidemics. ${ }^{92}$

90 Transport Proclamation No. 468/2005, Federal Negarit Gazeta, $11^{\text {th }}$ Year, No. 58, 6 August 2005

${ }^{91}$ Paul A. Freund (1942), 'The Emergency Price Control Act Of 1942: Constitutional Issues', Law and Contemporary Problems, Winter, p. 77 (emphasis given by this writer).

92 Natural disasters that need mass evacuations from a particular locality may require introducing tariff floors for transport services -a sector already regulated; or an outbreak of epidemic may necessitate medical service and medicine price control. 


\subsection{Price regulation: Federal vs. regional power}

As a federal political system, Ethiopia has adopted an approach whereby legislative, executive and judicial power is divided between the federal and the regional states. In relation to price regulation, it is reasonable to ask whether it is a federal or regional power to determine prices whenever such regulatory intervention is deemed necessary.

The Ethiopian constitution has provisions that seem to give power to the Federal Government over economic policy matters. Some of provisions of the Constitution in this regard include the power to regulate interstate commerce (Article 51/12), the power to legislate on civil law matters identified (by the HOF) as necessary for the creation and maintenance of one economic community (Article 55/6), and the emergency power under article 93.

The power to regulate interstate commerce is federal power in many federal constitutions. A similar clause in the US Constitution has been interpreted by the US Supreme Court as a basis for the Federal Government's price control legislation embodied in the Economic Stabilization Act of 1972..$^{3}$ Under the US Constitution's commerce clause, Congress is allowed to regulate "any activity which affects interstate commerce" and if prices are deemed to affect interstate commerce, the federal government can embark on price regulation. ${ }^{94}$ Despite the variance from the USA in terms of constitutional jurisprudence, there is no reason why the interstate commerce clause of the FDRE Constitution cannot be interpreted in a similar manner if price hampers interstate commerce in Ethiopia.

Furthermore, the Federal Government is empowered to "enact civil laws that the House of the Federation deems necessary to establish and sustain one economic community". ${ }^{95}$ Under this provision, economic regulation in general and price regulation in particular seem to be meant for the Federal Government. While, a comprehensive list of matters that relate to the creation and sustenance of one economic community has not been developed by the HoF, the intention of the Constitution is to vest these powers in the

\footnotetext{
93 John N. Drobak (1986), supra note 74, at note 8.

94 Jack Pine (1971), 'Constitutionality of the Delegation of Legislative Power to Control Prices, Rents, Wages, and Salaries: The Economic Stabilization Act of 1970’ 48 Chicago Kent Law Review, Vol. 48, p. 279.

${ }^{95}$ Art. 55(6) of the FDRE Constitution, supra note 67.
} 
hands of the Federal Government. ${ }^{96}$ It is readily understandable that should price regulation of one region be markedly different from another on the same economic activity, it surely can result in distorting the uniform economic community aspired in the Constitution. Entrepreneurs and investors may migrate to another regional state thereby adversely distorting economic development. However, regional states can regulate prices as an emergency power within the meaning of Article 93(1/b) of the Constitution in their respective territories, in the same way that the federal government can do at the national level. ${ }^{97}$

Therefore, one may argue that unless there is a state of emergency at a regional state level, regions cannot have this power apart from coordinating the implementation of price regulation that is made at the federal level. With regard to the basic commodity price regulations regions have been, in practice, implementing price regulation in accordance with the federal regulation. In the transport sector, however, regions seem to regulate tariffs in their own ways. ${ }^{98}$

\subsection{Legislation on price regulation}

Besides the Constitution, Proclamation No. 1097/2018 ${ }^{99}$ directly addresses the issue of price control. It gives power to regulate prices to the Council of Ministers upon the studies and proposals submitted by the Ministry of Trade and Industry. Article 19 (1)(j) of the Proclamation states that the Ministry shall "undertake and submit to the Council of Ministers studies relating to prices of basic commodities and services that require price control; [and] oversee implementation of same upon approval." This provision is very similar with the one under Article 25(1) of Trade Competition and

${ }^{96}$ See also the Preamble of the FDRE Constitution which states the overarching objective of creating one economic community.

${ }^{97}$ Almost all of the price control directives issued by the Ministry of Trade and Industry are addressed to each regional state Bureaus of Trade and Industry to be enforced uniformly. On the other hand, transport tariffs have been set by regions independently from the federal government. See an article by Haimanot Ashenafi, Tariff Adjustment Delights Transporters, Distresses Passengers, Addis Fortune, 1, April 2018. According to this newspaper article Oromia State Transport Authority raised transport tariffs without any similar activity at the federal level or in other regions. Available at https://addisfortune.net/columns/tariff-adjustment-delights-transporters-distressespassengers/ accessed on 28 April 2020.

98 See Haimanot Ashenafi, ibid.

${ }^{99}$ Definition of Powers and Duties of the Executive Organs of the Federal Democratic Republic of Ethiopia Proclamation No. 1097/2018, Federal Negarit Gazeta, 25 ${ }^{\text {th }}$ Year, No. 8, 28, November 2018 (hereinafter Executive Organs' Proclamation). 
Consumer Protection Proclamation No. 813/2013 (TCCP Proclamation). Article 25(2) of the TCCP Proclamation reinforces the price regulatory power of the state declaring that "it shall be prohibited to sell or attempt to sell basic goods or services beyond the price fixed by the government and announced by a public notice." Under Article 43(6) of the Proclamation, violation of this provision can result in a fine of up to 50,000 ETB or simple imprisonment.

Basic goods/commodities and services is defined (under the latter proclamation) as "goods or services related to the daily needs of consumers the shortage of which in the market may lead to unfair trade practices." Even though the definition of basic goods and services is wide, it has in practice been implemented often for controlling the price of cereals, edible oil and sugar. Apparently, the provision seems to be ambiguous as to where the ultimate power of price regulation is vested between the Council of Ministers and the Ministry. However, one can argue that the ultimate power to control prices is vested in the Council of Ministers than in the Ministry, since the latter implements price control which is approved by the Council of Ministers. That is why Article 25 of the TCCP Proclamation states that upon approval, the Ministry shall announce the list of goods and services and their prices by a 'public notice', than by directive which is the natural instrument of lawmaking at a Ministry level. This means, in a way, notifying the decision of the Council of Ministers (CM), than enacting a directive by itself.

The above two proclamations do not directly and clearly stipulate CM's power of approval (except that Proclamation No. 1097/2018 simply refers to Article 77 of the Constitution). It may thus be worthwhile to look at the said provision of the Constitution. Article 77(6) states that the CM "shall formulate and implement economic, social and development policies and strategies." On the other hand, Article 77(13) states that the CM shall "enact regulations pursuant to powers vested in it by the House of Peoples' Representatives." These sub-articles read in conjunction with Article 51(2, 9, and 12) as well as Art. 89(8) seem to be well in conformity with the above proclamation. In relation to fuel prices, the $\mathrm{CM}$ has issued decisions rather than a standard regulation, in terms of the form of the instrument. It seems that the temporary lifespan of fuel price which is often set for a month makes it inapt for a standard regulation.

On the other hand, despite the TCCP Proclamation, there is mixed practice with regard to prescribing public notice as a form of instrument for 
introducing price regulation. The ministry has used public notice for announcing the price of petrol on monthly basis, ${ }^{100}$ but has invariably used directives to regulate basic commodity prices. ${ }^{101}$ For instance, the latest price regulation instrument was the 'Basic Commodities Price, distribution and Control Directive No. 03/2011.' Strictly interpreted, this is contrary to Article 25 of the TCCP Proclamation, which calls for a public notice.

Regarding the forms of price regulation, a careful reading of Article 25 of TCCP Proclamation reveals that it is concerned with price caps than floors. However, the Proclamation deals indirectly with price floors in the context of abuse of market dominance under Article 5(2)(b). Under this provision, selling below cost of production is defined as an abuse of dominance, making the cost of production an indirect price floor. Price regulation may also occur with the objective of prohibiting anti-competitive price determination by cartels or collusions between traders under Article 7(1)(b) of the TCCP Proclamation. This provision prohibits agreements between traders involving "directly or indirectly, fixing a purchase or selling price." As this provision is concerned with price fixing by cartels, it can be used to introduce either floor prices or caps to counter the cartel price.

The other legal instrument that empowers the government to regulate prices is the Transport law. Road Transport Tariffs Council of Ministers' Regulations No. 2/1992 which aimed to liberalize the transport sector did not spare the issue of tariffs to the private sector as it provided that tariffs shall be proposed by the Transport Authority and approved by the Ministry of Transport and Communication. ${ }^{102}$ Accordingly, the transport regulator has been exercising the power to regulate fares and tariffs and this power is presently granted at the Federal level to the Transport Authority. Article 7(2)(g) of the Transport Authority Proclamation No. 468/2005 states that the Authority shall "approve tariff proposed by persons, organizations or associations engaged in cross-country and international passenger transport, taking into account the benefit they should get from the service provided and the capacity of the users to pay." This provision is a moderate version of the unilateral price control power that can be exercised by the government in relation to basic commodities. In effect, the Authority does not have the power to impose tariffs that are not proposed by the transport service providers, and transport providers cannot charge tariffs that have not been

\footnotetext{
${ }^{100}$ See section 4.2 below.

${ }^{101}$ See section 4.1 below.

102 IBIS Transport Consultants Ltd Public Private Infrastructure Advisory Facility Study of urban public transport conditions in Addis Ababa, Ethiopia, March (2005) p. 46.
} 
approved by the Authority. It is more of a shared regulation. However, transport tariff regulation has often followed fuel price changes made by the Council of Ministers. ${ }^{103}$

At the city level, the Addis Ababa City Transport Bureau has been setting fares and tariffs. But its power to do so does not appear in the proclamation establishing the Bureau. Article 43 that states the powers of the 'Road and Transport Bureau' does not provide any power in relation to price control. A provision close to giving tariff setting power under paragraph 3 states that the Bureau shall "devise mechanism for the improvement of transport service demand and supply system as well as management by conducting timely studies". ${ }^{104}$ This falls short of giving this key power in price control. Hence, the price regulation power of the City Government is arguably based on the Federal Transport Authority Directives.

Lastly, we can identify the list of laws that empower price regulation by looking at financial sector laws (mainly those of the insurance sector laws). While rate making in the banking sector such as interest rate regulation is an inherent central banking activity, it does not raise questions as it is clearly authorized under Article 51 of the Constitution. However, the authority for insurance premium controls is based in the proclamations. Under third party insurance proclamation, premium has been an area of regulation by law. Accordingly, Article 4(4) of the Vehicle Insurance against Third Party Risks Proclamation No. 799/2013 provides that "the premium tariff applicable to vehicle insurance policy against third party risks shall be determined by the Council of Ministers based on the study carried out and submitted by" the insurance Fund Administrations Agency. ${ }^{105}$ Therefore, the Agency had studied and submitted a premium tariff rate which was eventually approved by the Council of Ministers, and is in use by the third party motor insurance industry. ${ }^{106}$ In 2019, a law is enacted that empowers the National Bank of Ethiopia to regulate floor prices for all classes of insurance. Article 58 of

${ }^{103}$ See, Authority announces new tariffs on taxis, buses, nazret.com, January 272008 , available at:

http://nazret.com/blog/index.php/2008/01/27/ethiopia_authority_announces_new_tar iffs accessed on 25 April 2020.

104 Addis Ababa City Government Executive and Municipal Service Organs Reestablishment Proclamation No. 35/2012.

${ }^{105}$ Vehicle Insurance against Third Party Risks Proclamation No. 799/2013 Federal Negarit Gazzetta19thYear, No. 53, July 2013.

${ }^{106}$ Shimelis Tesfaye, (2015), The Implementation of Compulsory Motor Insurance in Ethiopia, AAU School of Graduate Studies, p. 24. Available at: 
Proclamation No. 1163/2019 states that "the National Bank may determine an economic (minimum) premium rate in a manner to be specified by a directive." $" 107$

\subsection{Recourse against price regulation}

Price regulation not only interferes with the freedom of contract, but it also "restricts the income terms of private contracts". ${ }^{108}$ Since the property (goods or service) subject to the price regulation is privately owned, an important question of procedural safeguards can be raised. We should thus characterize the concept of price regulation within the constitutional protection and the instruments of price regulation before embarking on the procedural safeguards, if any.

If price control interferes with the property rights of business or persons, there has to be a legal redress against such interference or infringement of rights, particularly when such regulation causes damage or is deemed to be arbitrary. However, it can be argued both in support and against protection of property rights in the context of price regulation. One way of looking at the issue can be to deem goods and services offered on the market as less protected than those in the private domain. If a person in business has some property rights over the goods and services he/she offers on the market, it can be assumed that "a business owner implicitly grants to the public a property interest when the owner uses the property in a manner that affects the general public."109

The opposing view would be not to make distinction as far as the property is the fruit of one's labor regardless of whether it is put to market or it remains in the domain of private enjoyment. Here it can be advisable to adopt the three tests applied by US courts for validity of price control in light of Article 40 of the Constitution. The requirements of public interest, the temporary nature of the control and the ability to withdraw from the regulated market should be used as guiding principles in allowing or disallowing such a regulation. Like the American case, a distinction can be made for utility firms. Utilities are both prone to opportunistic behavior; and at the same time, they can also be susceptible to opportunism by their customers. Due to their monopolistic nature "customers depending upon one firm for a particular utility service are subject to the firm's opportunistic

\footnotetext{
${ }^{107}$ Insurance Business (Amendment) Proclamation No. 1163/2019, Federal Negarit Gazetta, Year 26, No. 6, January 2020.

108 Steven N.S. Cheung, supra note 2, p. 56.

${ }^{109}$ Drobek, supra note 74, p. 120.
} 
behavior, thus utility regulation protects the customers' right to be served at a regulated price." ${ }^{110}$ On the other hand, as a result of the specialized assets, there is the tendency that "a government can set lower prices for these firms with greater likelihood that the firms will continue to sell their products at a regulated price." $" 11$

Be that as it may, there can be remedies for arbitrary and harmful price regulation by virtue of the new Federal Administrative Procedure Proclamation No. 1183/2020. ${ }^{112}$ Until this proclamation was enacted, there was no streamlined legal procedure for remedies if legislation and decisions unreasonably encroach upon rights. ${ }^{113}$ This Proclamation gives procedural safeguards for individuals and entities affected by administrative rulemaking such as notice, written comment and hearing prior to enactment of the directive. If these procedural requirements are not observed, the directive can be revoked by a court of law. Revocation will also be a possibility if a directive is ultra-vires, or against the principle of hierarchy of laws. ${ }^{114}$

\section{Major Price Regulation Exercises in Ethiopia}

The Ethiopian government has been regulating the prices of commodities and services in the market since the Military regime. After the fall of the military regime in 1991, price regulation was selectively implemented both as a permanent policy measure that is in respect of fuel prices and transport tariffs, and as ad-hoc measure in respect of the price of basic commodities. Despite the existence of a fairly strong legal basis for governmental price regulation, most of the instruments introducing price control do not recite the source of the authority for such regulations. Some of the major practical exercises of price control are presented below.

\subsection{Regulating the price of basic commodities}

Among the several policy measures taken by the Ethiopian government following the increase in prices of basic food items -especially since the advent of the new millennium-, price regulation stands out as the most

\footnotetext{
${ }^{110} \mathrm{Id}, \mathrm{p} .127$.

${ }^{111}$ Ibid.

${ }^{112}$ Federal Administrative Procedure Proclamation No. 1183/2020 Federal Negarit Gazzeta, Year 26, No. 32, April 2020.

${ }^{113}$ See generally, Aron Degol and Abdulatif Kedir (2013), 'Administrative Rulemaking in Ethiopia: Normative and Institutional Framework', 7(1) Mizan Law Review.

${ }^{114}$ Federal Administrative Procedure Proclamation No. 1183/2020, supra note 112, Art. 50 .
} 
controversial. Following these price hikes "policy makers strongly felt that staple foods cannot be left to market forces alone and took several measures to stabilize food prices and to improve the purchasing power of the most affected segments of the population, mostly the urban poor."115

In the 2011, "the government prescribed the maximum prices to be charged for selling grains and placed directives on private traders to use price tags on their goods and to post the list of their goods for sale with the corresponding prices." 116 In only the first round of the price control measure, 18 items were brought under the price cap. ${ }^{117}$ The 2011 price regulation was issued by a directive of the Ministry of Trade. But the detailed implementation was effected through a detailed implementation guideline in respect to each regulated item, and the guideline was dispatched to all trade bureaus of the regional states to be implemented uniformly. ${ }^{118}$ The guideline stipulated a detailed control structure on value chains, marketing places, storage and other issues in addition to regulating prices. ${ }^{119}$ At the regional level, Trade Bureaus were empowered to adjust the price ceilings factoring in the transportation cost, loading and unloading charges, etc. ${ }^{120}$

This policy of food price regulation was repeated during various periods whenever inflation drove food prices above desired levels. The regulation had continued until the following year (2012) at least with respect to edible oil, sugar, wheat, wheat flour and bread. ${ }^{121}$ A more recent price regulation exercise was made in 2016. ${ }^{122}$ The directive is limited in application to palm oil, wheat, wheat flour and bread which is supplied by the government through a special subsidy program, and does not apply to similar items or other items procured on the free market. ${ }^{123}$ This exclusion makes it more in tune with the free market principle of private autonomy and freedom of

\footnotetext{
115 Assefa Admassie (2014), 'The Political Economy of Food Price Policy in Ethiopia', [in Per Pinstrup-Andersen (edr.) Food Price Policy in an Era of Market Instability: A Political Economy Analysis, 2014, Oxford Scholarship Online, p. 8]

${ }^{116}$ Id, p. 9.

${ }^{117}$ Seid Hassan, supra note 71.

${ }^{118}$ See for instance, ‘Ph' $1-18 / 585$

${ }^{119}$ Ibid.

${ }^{120}$ Ibid.

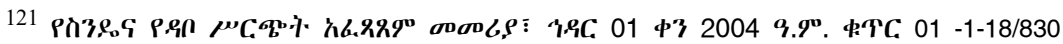

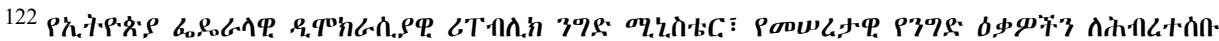
त

123 Id, Article 4.
} 
contract as far as it leaves out the items bought on the market from price control. $^{124}$

\subsection{Fuel price regulation}

The Ethiopian Government regulates the price of fuel, mainly gasoline, kerosene and diesel. The Ministry of Trade sets the price of fuel products at the beginning of every month, based on the authority vested on it by the Council of Ministers on October 3, 2008. ${ }^{125}$ Hence, by contrasting the previous month's price against the Ethiopian Petroleum Enterprise's procurement cost, the Ministry determines the price. ${ }^{126}$ Fuel price regulation has thus been a constant activity of the Ministry, which does not seem to be that controversial. Indeed, in even the most developed and liberal countries, the price of fuel has been a subject of control.

\subsection{Transport tariffs}

In the services sector, price regulation is applied by the government in different sectors. One of these sectors is the transport sector. The Federal Transport Authority has the power to "approve tariffs proposed by persons, organizations or associations engaged in cross-country and international passenger transport, taking into account the benefits they should get from the service provided and capacity of the users to pay." 127 In a way, this introduces a rather mixed control as tariffs should be proposed by operators in the first place. However, in the end, it is the Authority that controls price increase. The Authority can freeze tariffs by simply refusing to approve any proposal. ${ }^{128}$

It should be stressed that the provision deals with the country-level regulation, unlike the provision in sub-article 1, paragraph 1, where it gives broader power of national level control. In time of normalcy therefore, tariffs are to be determined by the regional authorities for intra-region transport. It

${ }^{124}$ It would be unjustified to assume that government cannot impose caps on commodities it imports and supplies to the market.

${ }^{125}$ See, the Fuel Price Notices, available online at: <http://www.mot.gov.et/fuel-price $>$ Accessed 12 August 2019.

${ }^{126}$ Ibid.

${ }^{127}$ Article 4(2)(g) of Transport Proclamation 468/2005, supra note 88.

${ }^{128}$ According to one Study, the Transport Authority properly takes into account requests of transport operators for increasing tariffs. See, 'The Management of Commercial Road Transport in Ethiopia', produced and distributed by the Addis Ababa Chamber of Commerce and Sectoral Associations with financial support from the Swedish Agency for International Development Cooperation, SIDA, 2009, p. 98. 
has thus been the practice that the Addis Ababa City Transport Bureau sets the tariffs within the city of Addis Ababa, ${ }^{129}$ in the same way the Federal Transport Authority determines for cross country transport. Likewise, Oromia region has also been doing the same. ${ }^{130}$

\subsection{Compulsory third party insurance premium}

The other area of service sector price control relates to premium rate for vehicle third party liability insurance. Article 4(4) of the Third Party Insurance Liability Proclamation 799/2013 states that ${ }^{131}$ "the premium tariff applicable to vehicle insurance policy against third party risks shall be determined by the Council of Ministers based on the study carried out and submitted by the Agency." Hence, Article 8(2) of the Insurance Fund Administration Agency Establishment Council of Ministers' Regulation No. 300/2012 states that the Agency shall "review and forward its proposals on policy matters relating to vehicle insurance against third party risks and studies on rates of premium and insurance fund tariff to be submitted pursuant to Article 4(4) and Article 23(2) of the Proclamation." Based on this provision, the Agency had submitted a premium rate approved by the Council of Ministers which is used as the rate of premium in the third party liability insurance industry.

\subsection{Other price regulation initiatives}

In addition to the foregoing, there are many areas of price control which are either in the pipeline or have been introduced. News reports were circulated a few years ago regarding the Ethiopian Government's plan to introduce rent control and cap on school fees at the primary and secondary levels. This has not materialized. Recently, the Ethiopian Football Federation and the Ministry of Culture and Sports have introduced caps on the salary of athletes in upper professional football clubs to curb salary inflation in sport. ${ }^{132}$

This can be taken as an example of arbitrary use of price regulation, and it is by no means an exceptional incident. There are other instances where price control is taken to remedy price increases. It is worrisome that price control is being taken as a panacea for every increase of prices.

\footnotetext{
${ }^{129}$ See above note 104.

${ }^{130}$ See an article by Haimanot Ashenafi, supra note 97.

${ }^{131}$ Vehicle Insurance against Third Party Risks Proclamation, supra note 105.

${ }^{132}$ Michael Samson, 'EEF's Newly Set Salary Cap Turned Controversial', Capital Newspaper, 19 August 2019, Available at: $<$ https://www.capitalethiopia.com/sports/effs-newly-set-salary-cap-turnedcontroversial/>. Accessed 12 August 2019.
} 


\section{Conclusions}

In a system of free market, "price controls are most frequently imposed in markets with natural monopoly or oligopoly components without free entry, where the undertaking(s) concerned are likely, absent intervention, to set prices near monopoly level." 133 The rationale for price regulation in such circumstances, is "typically, to prevent consumer exploitation through excessive retail prices, or to avoid market foreclosure, where high wholesale prices might obstruct downstream competition." 134 In Ethiopia, price regulation has not been made with such a motive or objective.

Price regulation in Ethiopia has always aimed at consumers. The various objectives and circumstances under which price control is introduced complicate the analysis on the legal basis of these regulations. From the economic perspective, while various investigations reveal that price control does not control inflation and scarcity of goods and services, it is the major motivation behind price control laws. Price control with social and competition objectives appears to be more effective in terms of achieving its intended objectives.

However, the food price regulations have not been successful in arresting inflation, or in improving the supply shortages. The underlying causes of inflation and commodity scarcity have remained unaddressed. Be that as it may, the constitutional and legal basis of price regulation is fairly solid. The Constitution grants the Federal Government enough powers to control prices both in times of emergency and in the absence of such emergency. However, it does not give any recourse mechanism for affected parties where the price regulation is arbitrary or if it disproportionally harms businesses.

As price control infringes property rights, there should thus be standards that can separate the arbitrary vis-à-vis the appropriate form of price control in the absence of state of emergency. During a state of emergency, the special considerations of the emergency situation (relevant to other emergency laws) should govern the proportionality and necessity of the price control. In the absence of state of emergency, however, the recently enacted Administrative Procedure Proclamation should serve as recourse mechanism against improper regulatory controls on prices.

\footnotetext{
${ }^{133}$ Niamh Dunne, supra note 4, p. 4. 134 Ibid.
} 